Article

\title{
Sustainability Viewed from Farmers' Perspectives in a Resource-Constrained Environment
}

\author{
Mariem Baccar ${ }^{1,2, *}$, Ahmed Bouaziz ${ }^{2}$, Patrick Dugué ${ }^{1}$, Mohamed Gafsi ${ }^{3}$ \\ and Pierre-Yves Le Gal ${ }^{1}$ \\ 1 CIRAD, UMR Innovation, 34398 Montpellier CEDEX 5, France; patrick.dugue@cirad.fr (P.D.); \\ pierre-yves.le_gal@cirad.fr (P.-Y.L.G.) \\ 2 Institut Agronomique et Vétérinaire Hassan II, BP 6202 Rabat-Instituts, 10100 Rabat, Morocco; \\ a.bouaziz@iav.ac.ma \\ 3 ENSFEA, UMR LISST-Dynamiques Rurales, 31326 Castanet Tolosan CEDEX, France; \\ mohamed.gafsi@educagri.fr \\ * Correspondence: mariem.baccar@cirad.fr; Tel.: +33-4-67-61-56-39
}

Received: 17 September 2020; Accepted: 16 October 2020; Published: 19 October 2020

\begin{abstract}
The way farmers perceive the concept of sustainability as applied to their own farms must be better understood in order to help them evolve towards more sustainable production systems. Based on extensive discussions with 36 farmers on the Saiis plain (Morocco), this article explores farmers' perceptions of sustainability and the strategies they are implementing for their farms to endure. Although these farmers are not formally aware of the concept of sustainability, they have several perceptions expressed through seven sustainability-related themes. The most frequently mentioned is the profitability of their agricultural activities (31\% of responses). Three groups of perception were identified through a multiple component analysis (MCA) and an ascending hierarchical cluster (AHC) analysis: A combination of economic profitability and maintenance of the farm's natural resources (Environment); a combination of economic profitability and a capacity to seize opportunities (Profitability); and setting up a modern agricultural model (Modernism). Additionally, farmers implement three types of strategies to endure also identified through MCA and AHC analysis: (1) Income security and farm survival with low-intensity practices involving farmers with low levels of investment (Security); (2) adaptation and valorization of the flexibility of the farm, bringing together farmers who intensify their practices according to economic opportunities (Adaptation); and (3) quest for productivity and income maximization for farmers with high levels of capital (Entrepreneurship). A certain coherence emerges between these two ways of grouping farms: Environment and Security linked to threats related to the degradation of soil fertility or water scarcity; Profitability and Adaptation in relation to land and economic opportunities; and Modernism and Entrepreneurship, which links economic sustainability, a modern production model, and capital accumulation.
\end{abstract}

Keywords: perception; production strategy; agricultural practices; farm typology; Morocco

\section{Introduction}

The limitations of the production-focused agricultural model based on the simplification of production systems and extensive use of non-renewable resources may be observed around the world [1]. These environmental, economic, and social limitations challenge this model [2] and call for a transition to more sustainable agriculture [3]. To be effective, transition processes must be adapted to farmers' diverse motivations and contexts of action $[4,5]$. To improve both the economic and environmental performance of farming systems, the ways that farmers perceive and transform their context of action to achieve sustainable development must be better understood and taken into account [6]. 
However, few studies have explored farmers' perceptions about the sustainability of their farms or the way they translate these perceptions into production strategies [7]. Studies generally focus on specific themes, such as soil degradation [8], the management of phytosanitary risks [5], biodiversity management [9], or the management of groundwater [10]. The few studies that explore how farmers perceive sustainability in a holistic way examine farmers' values in terms of the concept of sustainability [11], the influence of the socio-economic context on their perceptions [12], or what motivates farmers to integrate the concept into their practices [4]. These studies were implemented in contexts where farmers are generally familiar with the concept of sustainability.

As both the concept of 'sustainability' and the word itself can mean many different things [13], there is a widening gap between the discourse and actions of people (farmers, extension services, politicians, scientists) involved in sustainability debates, programs, and policies [14]. Thus, various authors have chosen to focus on the way farmers design and implement strategies to endure at the farm level in order to secure their income and the transgenerational continuity of their farm in a changing context [15-18]. Based on a survey conducted on a diversified sample of 36 farmers on the Saïs plain in Morocco, this paper aims to characterize how farmers translate their perceptions of farm sustainability into the design and implementation of their strategies to endure. Firstly, these perceptions are analyzed to go beyond the points of view of experts (researchers, politicians, industrialists). Secondly, the farmer's strategies to endure are characterized and finally compared with their perceptions of sustainability. These results and the methodology used in the study are then discussed in the light of current scientific debates on sustainability.

\section{Materials and Methods}

\subsection{Study Context}

The study was conducted on the Sais plain in Morocco, where for the past 45 years, agricultural dynamics have been driven by the capacity of family farmers to innovate in response to various opportunities offered to them. Starting from essentially rainfed agricultural systems (cereals, legumes, olives, and almond trees combined with extensive sheep and cattle farming), farmers have gradually turned to irrigated crops thanks to access to groundwater via individual wells. This transition to irrigated crops first involved market vegetables (onions and potatoes) and fruit trees (peach, plum, and grapes), which were managed intensively with a heavy use of inputs. Today, a large diversity of farms, determined by access to water, land, labor, and capital, as well as farmers' individual strategies, may be found on the Saïs plain.

A previous study of change trajectories enabled the identification of three farm types and seven sub-types [19]. T1 includes farms similar to the original traditional system, combining rainfed crops and livestock on land without access to water, varying according to their size: T1a comprises small farms ( 7 ha on average) and T1b large farms (about 100 ha on average). T2 groups together farms with access to irrigation and diversified production. T2a farms aim for total gross margins (TGM) derived in equal parts from rainfed crops, livestock, and horticulture (onions and potatoes). T2 b farms are oriented around fruit trees, which represent their principal source of income (over $50 \%$ of the TGM), followed by horticulture. T3 includes specialized farms regrouped into three subtypes. T3a farms are specialized in horticulture, which generates $70 \%$ of their TGM. T3b farms are specialized in arboriculture, which generates $80 \%$ of their TGM. T3c farms are specialized in dairy production.

The extension of irrigated crops, indicated by the increase in the number of wells (900 wells in the 1980s, over 12,000 wells and boreholes in 2012), has resulted in the overexploitation of the water table [20]. Moreover, the increase in the quantities produced (vegetables and recently fruit), a lack of farmers' organizations, and a limited capacity to store and process harvested crops have led to price volatility and the saturation of local and national markets. Between 2007 and 2013, the price of onions ranged from 1 to $7 \mathrm{MAD} / \mathrm{kg}(10 \mathrm{MAD}$ (Moroccan dirhams) $=0.93 €)$, and that of potatoes from 1 to $6 \mathrm{MAD} / \mathrm{kg}$ [21]. This development model, promoted today by the country's agricultural policy [22], 
has shown its limitations in other parts of the world through its negative effects on cultivated and natural ecosystems, and consequently on the sustainability of family farms [23]. All of these factors currently at play in the decision-making environment of farmers make Saïs an interesting area to study farmers' management strategies with regard to their strategies to endure in relation with their perceptions of farm sustainability.

\subsection{Sampling and Data Collection}

This study follows two previous studies on farms sustainability in the Saïs plain. The first aimed to understand the past dynamics of farms [19], the second to assess their current sustainability from an external point of view [24]. In the spirit of continuity, the same sample of 36 farmers interested in participating in this study was used. The sample size was deliberately small in order to conduct in-depth surveys of the technical and socio-economic processes driving the farmers' positions regarding sustainability. Additionally, the farms were selected in order to cover the large range of diversity found in the Saïs area regarding farm structure and type of production system (Table 1).

Table 1. Farm characteristics per farm type (average if not specified).

\begin{tabular}{|c|c|c|c|c|c|c|c|}
\hline \multirow{2}{*}{ Type } & \multicolumn{2}{|c|}{ Rainfed } & \multicolumn{2}{|c|}{ Diversified } & \multicolumn{3}{|c|}{ Specialized } \\
\hline & $\begin{array}{c}\text { T1a } \\
\text { Small }\end{array}$ & $\begin{array}{c}\text { T1b } \\
\text { Large }\end{array}$ & $\begin{array}{c}\text { T2a } \\
\text { Veg }^{a}\end{array}$ & $\begin{array}{l}\text { T2b } \\
\text { Fruit }\end{array}$ & $\begin{array}{l}\text { T3a } \\
\text { Veg }\end{array}$ & $\begin{array}{c}\text { T3b } \\
\text { Fruit }\end{array}$ & $\begin{array}{c}\text { T3c } \\
\text { Dairy }\end{array}$ \\
\hline Number of farms & 4 & 4 & 10 & 3 & 4 & 9 & 2 \\
\hline Total area (ha) & 7 & 98 & 10 & 13 & 19 & 19 & 32 \\
\hline Family MWU b & 2.3 & 2.8 & 1.9 & 2.2 & 2.5 & 1.7 & 1.8 \\
\hline$\%$ cultivated area Rainfed crops & 100 & 98 & 67 & 30 & 35 & 31 & 86 \\
\hline Irrigated vegetables & 0 & 0 & 26 & 44 & 58 & 6 & 0 \\
\hline Irrigated fruit trees & 0 & 0 & 2 & 24 & 3 & 62 & 0 \\
\hline Number of farms owning livestock Cattle & 3 & 2 & 8 & 2 & 3 & 4 & 2 \\
\hline Sheep & 2 & 3 & 5 & 0 & 2 & 0 & 0 \\
\hline Capital/MWU $\left({ }^{*} 1000\right.$ MAD $)$ & 213 & 953 & 565 & 539 & 614 & 1127 & 298 \\
\hline
\end{tabular}

${ }^{\mathrm{a}}$ Veg Vegetable; ${ }^{\mathrm{b}}$ MWU Man Work Unit.

Data were collected in two stages, using two different interviews modes. The first stage, based on non-directive interviews, focused on the way farmers perceived the notion of sustainability as applied to their own farm by collecting their values, judgments, and beliefs [25]. Since farmers were unaware of the concept of sustainability, this stage relied on an open-ended question: "What does 'a farm able to endure in the future' mean to you?" The time step of this future was left open (one year, several years, several generations). These interviews lasted on average $30 \mathrm{~min}$, during which farmers expressed themselves freely and their thoughts and speech were recorded. The second stage, based on semi-structured interviews, aimed to understand the production strategies implemented by farmers in order for their farms to endure. Five topics were discussed with the farmers. These were selected using criteria frequently employed in farming strategies studies and considered critical for an understanding of the continuity of family farms [17,26-28]: (i) Family dynamics, including the structure of the labor force, the number of generations living on the farm, the succession plan or other project considered for the next two years; (ii) land use dynamics, in particular the choice between direct tenure (running the farm themselves) and indirect tenure (leasing or joint use of land); (iii) farm economic performance, including farm income and capital invested; (iv) choice of production activities in relation to diversification or specialization strategies; and (v) production management practices, with a focus on irrigation, organic fertilization, and pesticide management. These interviews lasted on average an hour and a half.

\subsection{Data Analysis}

Farmers' perceptions of sustainability were characterized by conducting a content analysis of the transcripts of their responses and then by identifying the key elements (words or phrases) and 
classifying them into themes [29]. In their responses, some farmers provided a unique representation of sustainability, while for others sustainability involved several representations. Thus, a total of $91 \mathrm{key}$ elements were identified in the responses of the 36 farmers. These elements were coded and grouped under seven themes according to their similarity. The combinations of the different themes in the farmers' responses were identified through a multiple component analysis (MCA) and an ascending hierarchical cluster (AHC) analysis [30]. Indeed multivariate analyses are exploratory statistical tools adapted to a small sample as well [31]. They are useful when each individual is described with four variables or more, by showing a range of features and interactions between variables that are difficult to detect otherwise [32].

An inductive analysis of farmers' answers in the second stage interviews was conducted in parallel to understand how their production strategies reflected how they intended to ensure that their farm could endure. Examination of the responses led to the selection of eight variables accounting for the farmers' different strategies (Table 2). These variables were subjected to a second multivariate analysis (MCA, AHC), allowing for the consideration of the specificity of each farmer and their commonalities [33]. The farmers who shared similar strategies then were grouped together to form a type of strategy to endure. In the last part of the analysis, the links between perceptions of sustainability and strategies to endure were analyzed by comparing the two sets of types encountered [34,35]. Quotes from farmers were inserted into the text to illustrate their positions more concretely.

Table 2. Variables selected for the multivariate analysis of Saïs farmers' strategies to endure.

\begin{tabular}{ccc}
\hline Components & Measurement Variables & Type of Variable \\
\hline Family characteristics & Family MWU ${ }^{\mathrm{a}}$ \% of total MWU) & Quantitative \\
\hline Land tenure & $\begin{array}{c}\text { Increasing cultivated surface through indirect } \\
\text { tenure }\end{array}$ & Qualitative \\
\hline \multirow{2}{*}{$\begin{array}{c}\text { Economic characteristics } \\
\text { Choice and combination of } \\
\text { production activities }\end{array}$} & SMIG $/ \mathrm{MWU}$ & Quantitative \\
\cline { 2 - 3 } & Capital/MWU & Quantitative \\
\hline \multirow{2}{*}{\begin{tabular}{c} 
Production management practices \\
\cline { 2 - 3 }
\end{tabular}} & Area fertilized with manure (\% of the UAA ${ }^{\mathrm{c}}$ ) & Quantitative \\
\cline { 2 - 3 } & Pesticide management & Qualitative \\
\hline
\end{tabular}

${ }^{a}$ MWU man work unit; ${ }^{b}$ SMIG Guaranteed minimum wage corresponding to 28,000 MAD/year; ${ }^{c}$ UAA Utilised agricultural area.

\section{Results}

\subsection{Farmers' Perceptions of the Notion of Farm Sustainability}

We used the Arabic word "al estidama" as a translation of the term "sustainability" to refer to the capacity of a farm to endure. The farmers responses are regrouped into seven themes (Figure 1). Economic 'profitability' was the most frequently mentioned element ( $31 \%$ of responses) as an objective to achieve in order to ensure the future of the farm. Having a profitable operation ensures its continuity and family welfare: "Farming cannot be sustainable if it is not profitable. If a farmer spends to produce, he has to cover his expenses, maintain his farm and feed his family." (A16). "If you do not earn money, you fall behind until you disappear. Profits give you the hope to continue and status in your community" (A11).

'Modernization and productivity of agriculture' was the second theme mentioned $(15 \%$ of responses). Farm sustainability is thus linked to a modern vision of agriculture involving emancipation from traditional farming. Economic arguments are presented, such as enhanced efficiency thanks to capital and labor factors, the reduction of labor costs through mechanization, and the guarantee of high 
income, as are social arguments such as the independence of young people in relation to their parents. This model is reflected in various choices such as motorized mechanization, specialization, and a heavy use of synthetic inputs in order to control the production process. "Our farms must follow the same evolution as farms in Europe (...) where specialization allows more efficiency through improved yields" (A20). The farmers pursuing this model are considered by their community as models to emulate. "My neighbour has state-of-the-art machinery and consults Spanish engineers to manage his olive trees. He is breaking all production records (...). That is what I call true farming" (A12).

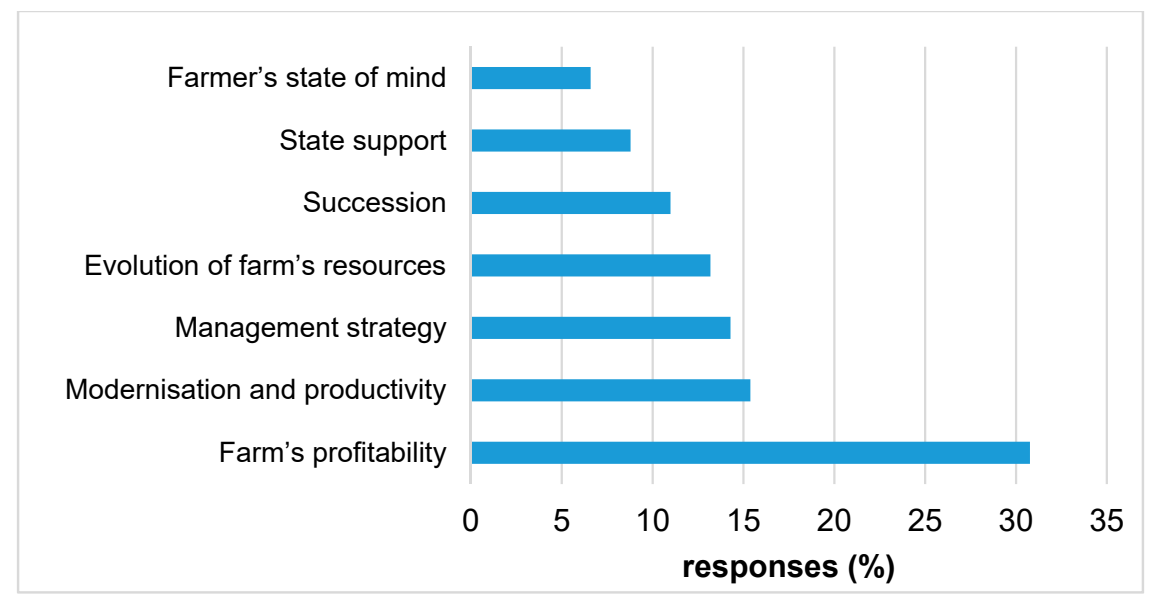

Figure 1. Distribution according to seven themes in the perception of a farm's sustainability (91 answers for 36 farmers interviewed).

For $14 \%$ of respondents, knowing how to identify and respond to external threats and opportunities determine a farm's sustainability. These farmers use terms such as "seize opportunities", "make the most of available opportunities", "limit risks", and "anticipate risk". These risks and opportunities involve changes in market prices, arrangements between farmers to increase their cash flows or respond to a lack of water or land resources, managing the workforce during peak periods, tapping into different types of subsidies, or the training of young people in modern agro-industrial techniques. "The geographic boundaries of a farm are no longer a limit. All farmers today work with others to expand the land they cultivate or even rent land (...). You have to be smart and make the most of opportunities that arise" (A31).

Only $13 \%$ of respondents link sustainability to the evolution of a farm's natural resources. These farmers are facing problems related to soil fertility and the availability of irrigation water, which lead them to highlight the environmental dimension of sustainability. The loss of fertility is reflected in the notion of "tired soil", assessed by the appearance of the surface horizon and by the evolution of the soil's production potential, such as crop yields under different production conditions. "Before we cultivated only part of our land, [the rest was left to lie fallow for varying periods] but recently we have been cultivating all of the land (...) thanks to the tractor and motor pump. But at the same time, we see that the fertility of our land is decreasing compared to 30 years ago" (A26). A decline in well levels is seen by an increasing number of farmers, and this is a real problem for two of them. "I know a lot of farmers who have seen their well levels drop in high onion season. Some manage to rent water rights and save their crop but others have to abandon part of their field" (A2). However, the farmers link no other environmental impact to the sustainability of their farms. Half of them are unaware of the existence of nitrate and pesticide water pollution, although this is an impact of their practices which is measured by the Sebou Water Basin Agency. "We know that there are environmental problems caused by industrial pollution, it is on T.V. (...). They talk about the effects of this pollution like irregular seasons and the lack of rain but no one mentions agricultural pollution. For example, I have no idea what goes on below the $20 \mathrm{~cm}$ of soil which I cultivate" (A2). The other half of the farmers are aware that agriculture has negative environmental impacts but feel that it would be impossible to farm without 
chemical inputs. They all feel that the State should assume responsibility for managing the effects of their practices. "The State gives us subsidies for irrigation; it manufactures or imports fertilizers and plant protection products to encourage farmers to produce. It is therefore solely responsible for the consequences of agriculture on the environment" (A36). "The environment is a common good, everyone is responsible: the State, citizens, consumers, farmers (...). Why should farmers worry if the others aren't?" (A11).

While these first four themes represent the majority of responses, three others related to social aspects each generated less than $10 \%$ of the responses. The succession and transmission of land capital are mentioned by farmers who perceive the sustainability of their farm through the capacity of their children to take it over once they have transmitted their know-how. Public, social (social security, retirement), and economic measures (production aid and market regulation) are perceived as facilitating the sustainability of farms. Finally, six farmers link this to the mindset of the farm head in terms of willingness to evolve and work hard.

Three groups of farmers emerge from the combination of these seven themes (Figure 2). The group 'Environment' gathers 17 farmers who perceive sustainability as a combination of economic profitability and the maintenance of a farm's water and land resources. This environmental concern is only found within this group in a view of sustainability limited to the farm level. The 'Profitability' group includes nine farmers who link the sustainability of their farm to economic profitability and their ability to seize opportunities and adapt to external constraints. The 10 farmers in the 'Modernism' group see sustainability as the implementation of a modern agricultural model. For these farmers, sustainable farming is an activity that bases its growth on technological innovations such as localized irrigation, fertigation, electric pumps and motorized sprayers, production with high added value (trellised grapevines), or even processing/conservation practices (prunes, cold storage). This modern, capitalistic form of agriculture is today encouraged by the State. It is brought to Saiis by investors who are targeting high and rapid returns on their investments.

\subsection{Three Types of Strategies to Endure}

Farmers implement three main strategies to endure and achieve their production, heritage, and family goals (Figure 3, Table 3).

Table 3. Average farm characteristics of the different strategies to last (number of farms concerned if not specified).

\begin{tabular}{cccc}
\hline & Security & Adaptation & Entrepreneurship \\
\hline Number of farms & 7 & 17 & 12 \\
Family MWU a (\% of total MWU) & 90 & 59 & 39 \\
Two generations present & 2 & 9 & 9 \\
Presence of livestock & 7 & 13 & 7 \\
UAA $^{\text {b }}$ (ha) & 7 & 19 & 41 \\
\% rainfed crops & 90 & 58 & 48 \\
\% irrigated market vegetables & 10 & 35 & 7 \\
\% irrigated arboriculture & - & 6 & 38 \\
\% organically fertilized & 35 & 15 & 4.3 \\
Polluting pressure c & 2.7 & 4.5 & 8 \\
Improvement of water availability & - & 8 & 9 \\
Recourse to private advisors & - & 2 & 7 \\
Recourse to subsidies & - & 9 & 12.7 \\
Income (SMIG dMWU) $_{\text {Capital/MWU (1000 *MAD) }}$ & 1.4 & 3.8 & 1103 \\
\hline
\end{tabular}

\footnotetext{
${ }^{a}$ MWU man work unit; ${ }^{b}$ UAA Utilised agricultural area; ${ }^{c}$ Polluting pressure corresponds to (dose applied $\times$ surface area treated)/(recommended dose * utilised agricultural area) * (weighting coefficient when applied manually); d SMIG Guaranteed minimum wage corresponding to 28,000 MAD/year.
} 

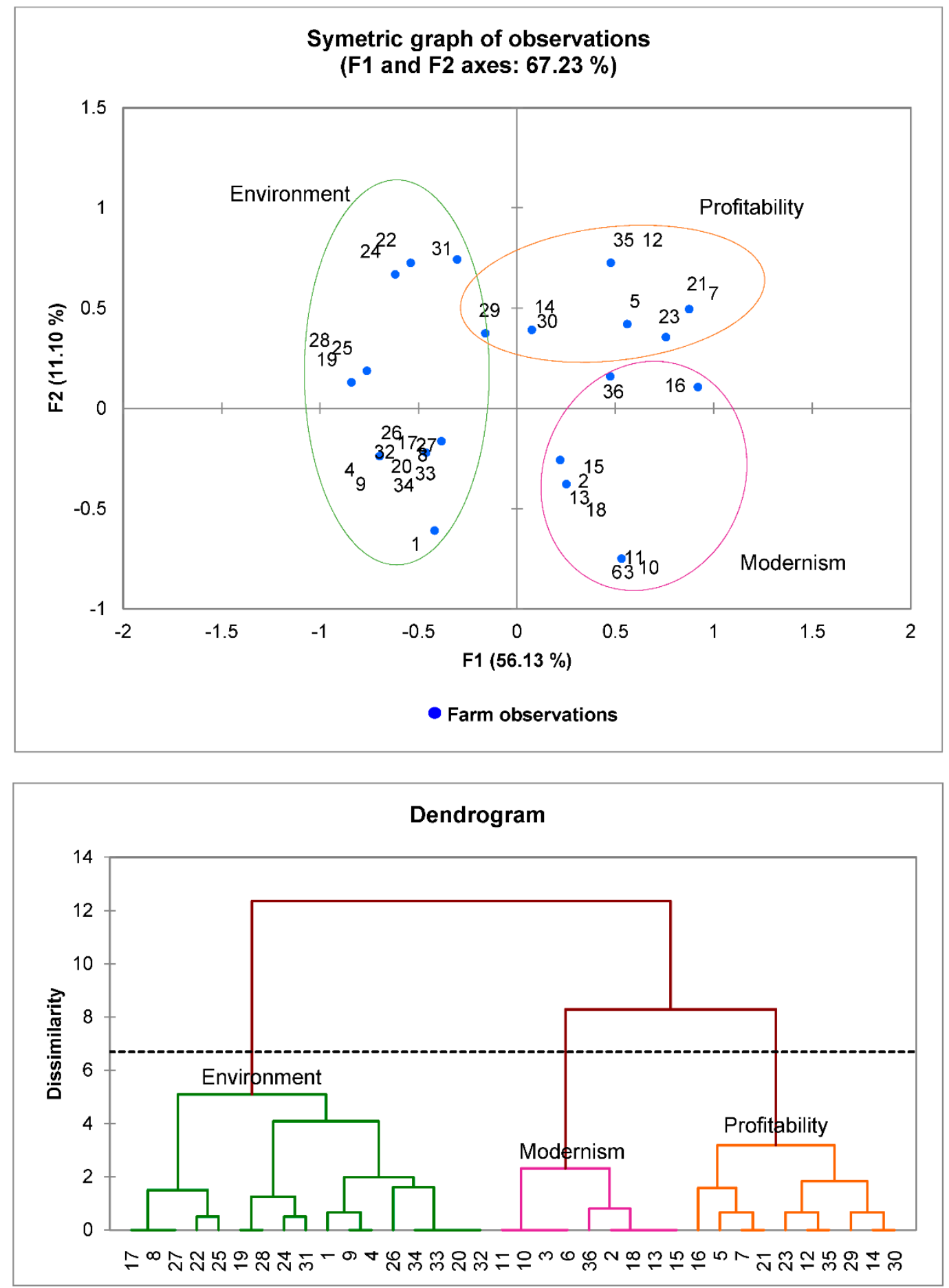

Figure 2. Distribution of the 36 farms in three sustainability definition groups based on the seven themes identified. The two MCA axes explain $67 \%$ of the variance. The three clusters identified by the ascending hierarchical cluster (AHC) (Environment, Profitability, Modernism) are shown on the multiple component analysis (MCA) graph by the three ellipses. 

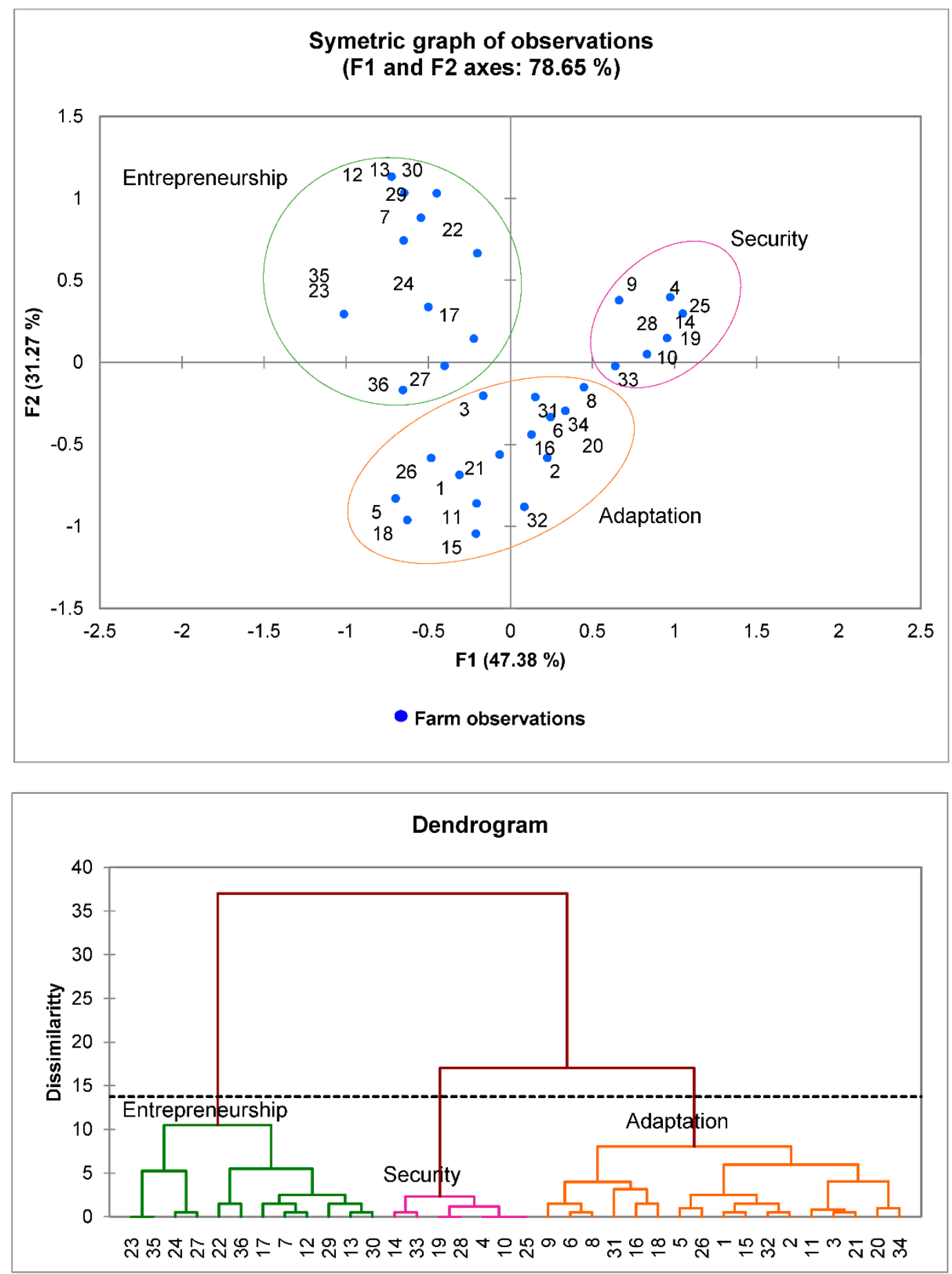

Figure 3. Multivariate analysis on the strategies to endure and coordinates of the 36 observations. The two MCA axes explain 79\% of the variance. The three strategy groups identified by the AHC (Security, Adaptation, Entrepreneurship) are indicated on the MCA graph by the three ellipses.

\subsubsection{Income Security and Farm Autonomy through Low-Intensity Practices}

The security strategy includes five farmers at the end of their careers whose sons have pursued careers outside agriculture, as well as two younger farmers who just inherited part of their family land, and therefore are cultivating small areas. These largely mono-generational farms have low incomes (1.4 SMIG (Guaranteed minimum wage corresponding to 28,000 MAD/year)/MWU (MWU man work unit)) and a low level of investment (292,000 MAD/MWU). These farmers adopt a production strategy that reduces risks and maximizes the resources available to them. They set up a diversified system 
based on a combination of rainfed crops, which have more stable prices and lower production costs, and semi-extensive livestock farming. The family's basic food needs (cereal, milk) are thus met while a small amount of capital in the form of live animals is maintained in case of drought or poor harvests. Most of the work on the farm is carried out by the family labor force, and seasonal workers are rarely called on.

Farming practices are not very intensive. Only three farmers had introduced irrigation. Soil fertility is managed through different crop rotations, including beans, and the application of the manure produced by the herd. Targeted pesticide use is based on the symptoms found in the crops, past experience, and the farmers' socio-professional network (other farmers, sellers of local products). These practices present the least pollution pressure (Equation (1)) in the sample.

$$
\mathrm{PP}_{\text {farm }}=\sum_{\mathrm{t}}\left(\frac{\mathrm{DA}_{\mathrm{t}}}{\mathrm{DR}_{\mathrm{t}}}\right) *\left(\frac{\mathrm{ST}_{\mathrm{t}}}{\mathrm{SA}}\right) \times \mathrm{k}
$$

with:

PP: pollution pressure at farm level

$\mathrm{t}$ : treatment index

DA: applied dose of pesticides (based on farmers' surveys for the 2012-2013 agricultural season)

DR: corresponding authorized dose

ST: spread area for treatment $t$ (based on farmers' surveys for the 2012-2013 agricultural season)

SA: total cultivated area

$\mathrm{k}: 2$ if the application is manual, 1 otherwise.

\subsubsection{Adaption and Valorization of the Farm's Flexibility according to Opportunities}

The adaptation strategy gathers 17 farmers, the majority of whom wish to pass their farms on to the next generation. Most plan to improve their production facilities over the next two years and take limited economic risks, which leads them to an average level of investment (560,000 MAD/MWU) and moderate incomes (3.8 SMIG/MWU). These incomes are deemed sufficient to continue agricultural activity while, when possible, putting aside some savings, based on a diversity of crops (seven commodities on average) and a herd (13 cases) intended to be either a significant source of income (milk, meat) or a traditional form of standing savings.

The various production systems of this group aim to maintain a certain degree of flexibility through the adjustment of different activities to changes such as falling product prices, rising input prices, technical problems (resistance of certain crops to disease, reduced yields), or income-earning opportunities. Annual crops dominate (cereals to secure income and as livestock feed, irrigated market gardening on 15 farms to increase income), while arboriculture only covers $6 \%$ of the surface area. "The rule is that with onions, you win one year and lose the next (...), but this is not always true. Some lucky farmers who bet on large areas of onions at the right time got rich at the end of just one season; but this strategy is dangerous because if there are losses, it can take years to recover" (A5). Opportunities for increasing income come in the form of subsidies paid by the State (9 cases), or arrangements between farmers to increase cultivated land (association or sharecropping, leasing) or to compensate for a lack of water on the farm (8 cases). "A good farmer is a farmer who tries to improve his situation, for example, I have been renting land for 5 years, this strategy lets me make the most of the workforce and my family's know-how while improving my income." (A8).

The combination of agriculture with livestock and the diversity of crops make it possible to manage soil fertility through long rotations and the use of the manure produced, which is devoted first for growing potatoes (12 farmers). However, the organically fertilized area remains small, so the use of mineral fertilizers remains high. As in the security strategy, the use of pesticides is linked to the level of infestation of bio-aggressors, but can take more intensive forms if it allows a better valorization of the product (storage, payment based on the product's appearance). As a result, these farms show the highest pollution pressure. "Crop diseases have increased in recent years because of 
climate conditions. Before, we only treated onions three times, now just some mist is reason enough to treat, up to 9 treatments per cycle are possible. The number of treatments increases if we plan to store the onions, we must block germination during the storage period" (A16).

Eight farmers with the necessary capital have already improved their water availability (deepening wells, storage basins, boreholes) and six farmers plan to do so in the near future. "This water is essential for our business and no farmer can envisage a return to rainfed crops and traditional agriculture; as long as there are solutions to access this water, and the State continues to allow the digging of new wells, why change our practices?" (A26). Family labor remains dominant on the farm and does most of the work, but the use of seasonal or permanent workers is more frequent than in the security strategy, with the accompanying constraints. "Agricultural workers are starting to be a problem for farmers in Saïs because during peak periods [transplanting and harvesting of market vegetables] there are not enough workers and they become demanding, expensive and sometimes work only part-time" (A13).

\subsubsection{Entrepreneurial Strategy Seeking Productivity and Maximum Income}

The 12 farmers in this group have a strategy combining investments and a capital-intensive production system, with the aim of transmitting an effective work tool to their children, many of whom work on the farm (nine cases). The level of investment is high in comparison with other groups (1,103,000 MAD/MWU), in the form of agricultural equipment (tractor, combine harvester, milking machine), irrigation equipment to secure production (head station, localized irrigation, well/borehole, basin), orchards, and herds with high genetic potential. Their incomes are consistent with the investments made (12.7 SMIG/MWU). These production systems rely heavily on skilled wage labor (71\% of MWUs), with the family workforce focusing on farm management and reducing its participation in manual farming tasks.

These farms are for the most part specialized in lucrative productions, mainly in arboriculture (nine cases) or dairy production (one case). Two farmers have opted for a rainfed system (cereals, seed legumes) on large areas that do not have access to water and are inexpensive to rent. These choices are accompanied by a strong link to the market, leading them to exploit production opportunities in the event of market saturation. "If the price of peaches drops, I can uproot the peach trees and plant species which are rare in the area such as apricots or khaki" (A22). In addition to irrigation, efforts to secure yields involve the use of private advisors and recommended preventive practices. Phytosanitary treatments are thus applied following calendars established at the beginning of the campaign/crop cycle regardless of the actual pressure of the bio-aggressors, resulting in high polluting pressure (4.3). Soil fertility management appears under two practices in this group. A first group of farmers (six cases) favor mineral fertilization (manure on $14 \%$ of the UAA) due to reasons of availability, cost, and ease of spreading. These opportunistic farmers only apply organic fertilizers in the event of a critical drop in soil fertility. A second group of farmers (six cases) use organic fertilization on large areas of the farm (manure on $60 \%$ of the UAA). This choice is motivated by the presence of livestock on certain farms and by the agronomic interest perceived by the farmers.

\subsection{Linking Farmers' Sustainability Perceptions with Their Strategies to Endure}

Crossing the perceptions of sustainability groups and the farm management strategy groups shows that a same type of perception corresponds to different strategies (Figure 4). The presence of 'Environment' farmers in the three types of strategies shows that the degradation of soil fertility and water scarcity represent potential or real threats to the sustainability of all Saiis farms. 'Security' farmers in decline or facing strong economic constraints are particularly sensitive. Their search for autonomy linked to their lack of capital is in fact dependent on the state of their farms' water and organic resources. However, this also applies to a majority of 'Adaptation' farmers who observe a decline in soil fertility with market gardening, while seeking to secure their water resource through new boreholes or extensions of irrigable land. Four 'Entrepreneurship' farmers are also sensitive to the 
environmental component of their agricultural activities, although they are supposed to better control these through investments in access to water and the use of mineral fertilizers. Mineral fertilization is seen by these farmers as potentially harmful to the environment, but necessary due to a lack of available organic manure.

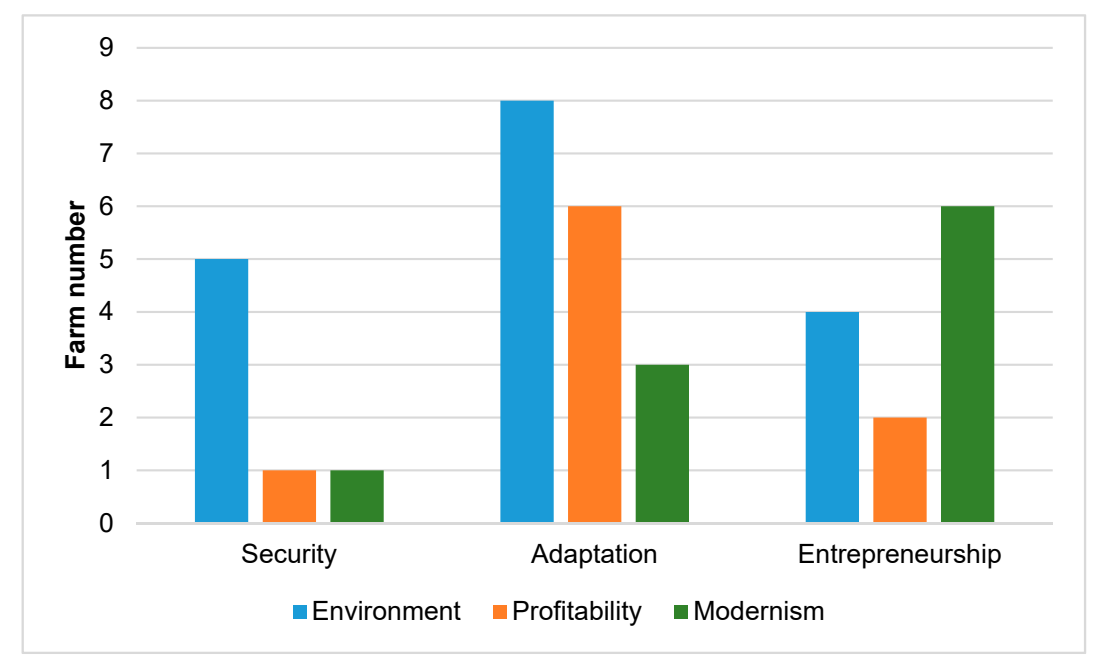

Figure 4. Comparison between perceptions of sustainability groups and strategies to last groups.

'Profitability' farmers also appear in all three strategies, but with a large majority in 'Adaptation', a strategy based on the flexibility of the farm, making the most of opportunities, whether land, hydraulic, or economic, and the implementation of more intensive practices considered apt to improve the economic sustainability of the farm. This coherence between the perception of sustainability and the management strategy is also found in 'Modernism', where most farmers adopt an Entrepreneurship strategy that concretely translates the link between sustainability and a modern production model. The 'Environment' and 'Profitability' strategies encountered in 'Entrepreneurship' are the result of farmers with projects linked to a desired future but still constrained by their lack of capital. There is thus overall a strong link between the perception of economic sustainability and farm management strategy, and a more individual perception of environmental sustainability, a function of (i) farmers' sensitivity to these issues, (ii) production contexts in which they are evolving in terms of access to water and soil fertility, and (iii) their capacity to respond through their available capital and access to organic fertilizers.

\section{Discussion}

\subsection{Farmers' Perceptions and Strategies to Endure Viewed through the Concept of Sustainability}

Numerous definitions of the sustainability concept have arisen from different disciplines and perspectives [14], and the concept encompasses diverse meanings depending on the interests of those using it $[36,37]$. In our case, although the farmers were not formally aware of the concept of sustainability, they expressed different representations of what the term sustainability meant in relation to their farm and their interests and value systems [25].

Economic concerns dominated the responses and arguments of Saïs farmers about sustainability. These concerns, which integrate issues of investment, available capital, profitability, and the efficiency of management processes, are deemed to be a priority for all farmers wondering "what must be done to endure?" $[9,38]$. This is consistent with the strong political incentives that have driven farmers for decades [34], rendering productivist values the standard of contemporary agricultural practices and models [39]. With the Green Morocco Plan, Moroccan agricultural policy aligns itself with this scheme by encouraging mass production through subsidies for mechanization, localized irrigation, and the creation of orchards [22]. The strategies to endure implemented by the farmers surveyed are consistent 
with their economic priority, while remaining linked to the realities of each farm, through the search for either income security with regard to threats to the farm, flexibility to seize opportunities, or high productivity and income.

However, natural resources were obviously an important component of sustainability as reflected in farmers' responses and management strategies. This component nonetheless was restricted to processes directly experienced at the farm level, such as water scarcity or the degradation of soil fertility. These processes also could involve shared resources, such as groundwater. Indeed, while $72 \%$ of the farmers surveyed were aware that this resource was being overexploited, each continued to search for individual solutions based on their own needs, seeking wherever possible to access more groundwater. Such actions may eventually lead to the exclusion of farmers who lack the necessary capital to access the resource, and led to a local social crisis [40]. The implementation of multi-stakeholder consultation frameworks involving farmers is therefore urgently needed to initiate effective aquifer management [41,42].

Many farmers were either unaware of the effects of agricultural practices on natural resources and the environment, or did not associate these effects with their own activities due to a lack of knowledge or information [43]. Since environmental sustainability involves broader levels of organization, such as the territory, where various stakeholders are concerned [44], farmers must switch from an individual perspective of sustainability to an extended one integrating an environmental awareness at the collective scale [45]. In the Saiis plain, this move depends on the social capital available to each farmer to seize opportunities involving learning (know-how), product marketing, land extension, mutual aid, etc. These social capital networks should be mobilized to raise farmers' awareness of the environmental impacts of agriculture, and to encourage any collective initiative aiming to better manage shared resources [46,47].

\subsection{Public Instruments Linked to Sustainability and Changes in Farmers' Practices}

This study shows a relatively close but not strict link between farmers' perceptions of the sustainability of their farms and the technical and environmental management strategies they implement. This relationship forms the basis of the "gap" highlighted by some authors in sustainable agriculture support programs between the positions of farmers and those who develop the programs due to a neglect of farmers' perceptions and knowledge $[6,48]$. These programs propose a range of technical recommendations, such as conservation agriculture, integrated predator management or even biological control, or groundwater conservation, which are intended to replace production practices based on synthetic inputs [34]. However, farmers may be reluctant to make changes if they feel that their farms' economic sustainability may be threatened by them, as shown by the relative failure of the French pesticide reduction plan [49].

In addition to regulations, public financial incentives such as payments for environmental services often appear to be critical to overcome these concerns [50]. Training in various forms (farmer field schools, innovation platforms, pilot experiments) is also a means of encouraging farmers to adopt environmentally friendly practices when these programs take into account the needs and preferences of the beneficiaries [51,52]. Lastly, the move towards more environmentally friendly practices assumes that farmers interact with other stakeholders within sectors and territories to improve exchanges of information, and that different viewpoints are considered, including, for example, consumer preferences [53] or the needs of processing industries. This could result in the establishment of certifications and standards that are powerful tools for changing practices [54]. These changes cannot be limited to farmers' decisions alone and must involve all stakeholders up to the consumers [47].

\section{Conclusions}

The concept of sustainability applied to farms refers to many variables and processes. In a context like the Saïs plain, where there is a combination of agricultural intensification and constraints on water and soil resources, farmers have a narrow interpretation of sustainability focused on the economic 
dimension applied to their own situation. This interpretation leads them to adopt exploitative behavior with regard to natural resources, particularly groundwater, which is managed as a private rather than a common resource.

The environmental dimension of sustainability is neglected by all farms except limited-capital farms, which are led to implement strategies based on resource autonomy. Developing productive, cost-effective, and environmentally friendly production systems will require coordinated action by various stakeholders involved in the agricultural sector, including consumers. A move in this direction appears difficult to achieve, a fortiori in a country where a large part of the wealth comes from the agricultural and agri-food sector.

Author Contributions: Conceptualization, M.B., M.G., P.D., A.B. and P.-Y.L.G.; methodology, M.B., M.G., P.D., A.B. and P.-Y.L.G.; validation, M.G. and P.-Y.L.G.; formal analysis, M.B.; investigation, M.B.; resources, A.B. and P.D.; data curation, M.B.; writing—original draft preparation, M.B.; writing—review and editing, M.B., M.G., P.D., A.B. and P.-Y.L.G.; visualization, M.B.; supervision, P.D., A.B. and P.-Y.L.G.; project administration, P.D., A.B. and P.-Y.L.G.; funding acquisition, P.D., A.B. and P.-Y.L.G. All authors have read and agreed to the published version of the manuscript.

Funding: This research was funded by the Groundwater ARENA projects, grant number ANR CEP S 11/09 and the Programme Hubert Curien Toubkal.

Acknowledgments: The authors would like to acknowledge the family farmers who accepted to be involved in the study. They are also grateful to Grace Delobel for her contribution to the English edition.

Conflicts of Interest: The authors declare no conflict of interest. The funders had no role in the design of the study; in the collection, analyses, or interpretation of data; in the writing of the manuscript, or in the decision to publish the results.

\section{References}

1. Lemaire, G.; Franzluebbers, A.; Carvalho, P.C.; Dedieu, B. Integrated crop-livestock systems: Strategies to achieve synergy between agricultural production and environmental quality. Agric. Ecosyst. Environ. 2014, 190, 4-8. [CrossRef]

2. Evans, N. Adjustment strategies revisited: Agricultural change in the Welsh Marches. J. Rural Stud. 2009, 25, 217-230. [CrossRef]

3. Swilling, M.; Musango, J.; Wakeford, J. Developmental States and Sustainability Transitions: Prospects of a Just Transition in South Africa. J. Environ. Policy Plan. 2016, 18, 650-672. [CrossRef]

4. Schoon, B.; Te Grotenhuis, R. Values of farmers, sustainability and agricultural policy. J. Agric. Environ. Ethics 2000, 12, 17-27. [CrossRef]

5. Schreinemachers, P.; Balasubramaniam, S.; Boopathi, N.M.; Ha, C.V.; Kenyon, L.; Praneetvatakul, S.; Sirijinda, A.; Tuan Le, N.; Srinivasan, R.; Wu, M.H. Farmers' perceptions and management of plant viruses in vegetables and legumes in tropical and subtropical Asia. Crop Prot. 2015, 75, 115-123. [CrossRef]

6. Fairweather, J.R.; Hunt, L.M. Can farmers map their farm system? Causal mapping and the sustainability of sheep/beef farms in New Zealand. Agric. Hum. Values 2011, 28, 55-66. [CrossRef]

7. Lankester, A. Self-perceived Roles in Life and Achieving Sustainability on Family Farms in North-eastern Australia. Aust. Geogr. 2012, 43, 233-251. [CrossRef]

8. Assefa, E.; Hans-Rudolf, B. Farmers' Perception of Land Degradation and Traditional Knowledge in Southern Ethiopia-Resilience and Stability: farmers' perception of land degradation and traditional knowledge. Land Degrad. Dev. 2016, 27, 1552-1561. [CrossRef]

9. Kelemen, E.; Nguyen, G.; Gomiero, T.; Kovács, E.; Choisis, J.P.; Choisis, N.; Paoletti, M.G.; Podmaniczky, L.; Ryschawy, J.; Sarthou, J.P.; et al. Farmers' perceptions of biodiversity: Lessons from a discourse-based deliberative valuation study. Land Use Policy 2013, 35, 318-328. [CrossRef]

10. Bekkar, Y.; Kuper, M.; Errahj, M.; Faysse, N.; Gafsi, M. On the difficulty of managing an invisible resource: Farmers' strategies and perceptions of groundwater use, field evidence from Morocco. Irrig. Drain. 2009, 58, S252-S263. [CrossRef]

11. Fairweather, J.R.; Campbell, H.R. Environmental Beliefs and Farm Practices of New Zealand Farmers: Contrasting Pathways to Sustainability. Agric. Hum. Values 2003, 20, 287-300. [CrossRef] 
12. Füsun Tatlıdil, F.; Boz, İ.; Tatlidil, H. Farmers' perception of sustainable agriculture and its determinants: A case study in Kahramanmaras province of Turkey. Environ. Dev. Sustain. 2009, 11, 1091-1106. [CrossRef]

13. White, M.A. Sustainability: I know it when I see it. Ecol. Econ. 2013, 86, 213-217. [CrossRef]

14. Bolis, I.; Morioka, S.N.; Sznelwar, L.I. When sustainable development risks losing its meaning. Delimiting the concept with a comprehensive literature review and a conceptual model. J. Clean. Prod. 2014, 83, 7-20. [CrossRef]

15. Rueff, C.; Choisis, J.P.; Balent, G.; Gibon, A. A Preliminary Assessment of the Local Diversity of Family Farms Change Trajectories Since 1950 in a Pyrenees Mountains Area. J. Sustain. Agric. 2012, 36, 564-590. [CrossRef]

16. Ryschawy, J.; Choisis, N.; Choisis, J.P.; Joannon, A.; Gibon, A. Mixed crop-livestock systems: An economic and environmental-friendly way of farming? Animal 2012, 6, 1722-1730. [CrossRef] [PubMed]

17. Ryschawy, J.; Choisis, N.; Choisis, J.P.; Gibon, A. Paths to last in mixed crop-livestock farming: Lessons from an assessment of farm trajectories of change. Animal 2013, 7, 673-681. [CrossRef]

18. Suess-Reyes, J.; Fuetsch, E. The future of family farming: A literature review on innovative, sustainable and succession-oriented strategies. J. Rural Stud. 2016, 47, 117-140. [CrossRef]

19. Baccar, M.; Bouaziz, A.; Dugué, P.; Le Gal, P.Y. Shared environment, diversity of pathways: Dynamics of family farming in the Saïs Plain (Morocco). Reg. Environ. Chang. 2017, 17, 739-751. [CrossRef]

20. Faysse, N.; EL Amrani, M.; EL Aydi, S.; Lahlou, A. Formulation and implementation of policies to deal with groundwater overuse in morocco: Which supporting coalitions? Policies to deal with groundwater overuse in morocco. Irrig. Drain. 2012, 61, 126-134. [CrossRef]

21. Lejars, C.; Courilleau, S. Impact du développement de l'accès à l'eau souterraine sur la dynamique d'une filière irriguée. Le cas de l'oignon d'été dans le Saïs au Maroc. Cah. Agric. 2014, 24, 1-10. [CrossRef]

22. Akesbi, N. Une nouvelle stratégie pour l'agriculture marocaine: Le Plan Maroc Vert. New Medit 2012, 11, 12-23.

23. Tilman, D.; Cassman, K.G.; Matson, P.A.; Naylor, R.; Polasky, S. Agricultural sustainability and intensive production practices. Nature 2002, 418, 671-677. [CrossRef] [PubMed]

24. Baccar, M.; Bouaziz, A.; Dugué, P.; Gafsi, M.; Le Gal, P.Y. The determining factors of farm sustainability in a context of growing agricultural intensification. Agroecol. Sustain. Food Syst. 2019, 43, 386-408. [CrossRef]

25. Thompson, P.B. Agricultural sustainability: What it is and what it is not. Int. J. Agric. Sustain. 2007, 5, 5-16. [CrossRef]

26. Chatterjee, S.; Goswami, R.; Bandyopadhyay, P. Methodology of identification and characterization of farming systems in irrigated agriculture: Case study in west Bengal State of India. J. Agric. Sci. Technol. 2015, $17,1127-1140$.

27. Choisis, J.P.; Thévenet, C.; Gibon, A. Analyzing farming systems diversity: A case study in south-western France. Span. J. Agric. Res. 2012, 10, 605-618. [CrossRef]

28. Ryschawy, J.; Choisis, N.; Choisis, J.P.; Joannon, A.; Gibon, A. Quelles stratégies pour un maintien de la polyculture-élevage? Une étude des trajectoires passées d'exploitations dans les coteaux de Gascogne. In L'agriculture En Famille: Travailler, Réinventer, Transmettre; Gasselin, P., Choisis, J.P., Petit, S., Purseigle, F., Zasser, S., Eds.; EDP Sciences: Les Ulis, France, 2015; pp. 287-304.

29. Elo, S.; Kyngäs, H. The qualitative content analysis process. J. Adv. Nurs. 2008, 62, 107-115. [CrossRef]

30. Bijnen, E.J. Cluster Analysis: Survey and Evaluation Techniques; Tilberg University Press: Tilberg, The Netherlands, 1973; p. 112. [CrossRef]

31. Shaukat, S.S.; Rao, T.A.; Khan, M.A. Impact of sample size on principal component analysis ordination of an environmental data set: Effects on eigenstructure. Ekológia (Bratislava) 2016, 35, 173-190. [CrossRef]

32. Jung, S.; Lee, S. Exploratory factor analysis for small samples. Behav. Res. 2011, 43, 701-709. [CrossRef]

33. Howard, R.J.; Tallontire, A.M.; Stringer, L.C.; Marchant, R.A. Which "fairness", for whom, and why? An empirical analysis of plural notions of fairness in Fairtrade Carbon Projects, using Q methodology. Environ. Sci. Policy 2016, 56, 100-109. [CrossRef]

34. Lincoln, N.K.; Ardoin, N.M. Cultivating values: Environmental values and sense of place as correlates of sustainable agricultural practices. Agric. Hum. Values 2016, 33, 389-401. [CrossRef]

35. Shucksmith, M.; Herrmann, V. Future changes in British agriculture: Projecting divergent farm household behaviour. J. Agric. Econ. 2002, 53, 37-50. [CrossRef]

36. Bond, A.; Morrison-Saunders, A.; Pope, J. Sustainability assessment: The state of the art. Impact Assess. Proj. Apprais. 2012, 30, 53-62. [CrossRef] 
37. Gafsi, M.; Legagneux, B.; Nguyen, G.; Robin, P. Towards sustainable farming systems: Effectiveness and deficiency of the French procedure of sustainable agriculture. Agric. Syst. 2006, 90, 226-242. [CrossRef]

38. Carr, S.; Tait, J. Differences in the attitudes of farmers and conservationists and their implications. J. Environ. Manag. 1991, 32, 281-294. [CrossRef]

39. Stock, P.V. "Good farmers" as reflexive producers: An examination of family organic farmers in the US Midwest. Sociol. Rural. 2007, 47, 83-102. [CrossRef]

40. Ameur, F.; Lejars, C.; Dugué, P.; Kuper, M. Prosper, survive or exit: Contrasted fortunes of farmers in the groundwater economy in the Sais plain (Morocco). Agric. Water Manag. 2017, 191, 207-217. [CrossRef]

41. Kuper, M.; Faysse, N.; Hammani, A.; Hartani, T.; Marlet, S.; Hamamouche, M.F.; Ameur, F. Liberation or Anarchy? The Janus Nature of Groundwater Use on North Africa's New Irrigation Frontiers. In Integrated Groundwater Management; Jakeman, A.J., Barreteau, O., Randall, J., Hunt, R.J., Rinaudo, J.D., Ross, A., Eds.; Springer International Publishing: Cham, Switzerland, 2016; pp. 583-615. [CrossRef]

42. Lejars, C.; Fusillier, J.L.; Bouarfa, S.; Coutant, C.; Brunel, L.; Rucheton, G. Limitation of agricultural groundwater uses in Beauce (France): What are the impacts on farms and on the food processing sector? Irrig. Drain. 2012, 61, 54-64. [CrossRef]

43. Khan, M.; Mahmood, H.Z.; Damalas, C.A. Pesticide use and risk perceptions among farmers in the cotton belt of Punjab, Pakistan. Crop Prot. 2015, 67, 184-190. [CrossRef]

44. Aubry, C.; Ramamonjisoa, J.; Dabat, M.H.; Rakotoarisoa, J.; Rakotondraibe, J.; Rabeharisoa, L. Urban agriculture and land use in cities: An approach with the multi-functionality and sustainability concepts in the case of Antananarivo (Madagascar). Land Use Policy 2012, 29, 429-439. [CrossRef]

45. Ingram, J. Agronomist-farmer knowledge encounters: An analysis of knowledge exchange in the context of best management practices in England. Agric. Hum. Values 2008, 25, 405-418. [CrossRef]

46. Cross, R.; Ampt, P. Exploring Agroecological Sustainability: Unearthing Innovators and Documenting a Community of Practice in Southeast Australia. Soc. Nat. Resour. 2017, 30, 585-600. [CrossRef]

47. Diehl, J.A.; Bose, M.; Main, D.S. A Social and Spatial Network Approach to Understanding Beliefs and Behaviors of Farmers Facing Land Development in Delhi, India. In Cities as Spatial and Social Networks. Human Dynamics in Smart Cities; Ye, X., Liu, X., Eds.; Springer: Cham, Switzerland, 2019; pp. 73-99. [CrossRef]

48. Sereke, F.; Dobricki, M.; Wilkes, J.; Kaeser, A.; Graves, A.R.; Szerencsits, E.; Herzog, F. Swiss farmers don't adopt agroforestry because they fear for their reputation. Agrofor. Syst. 2016, 90, 385-394. [CrossRef]

49. Guichard, L.; Dedieu, F.; Jeuffroy, M.H.; Meynard, J.M.; Reau, R.; Savini, I. Le plan Ecophyto de réduction d'usage des pesticides en France: Décryptage d'un échec et raisons d'espérer. Cah. Agric. 2017, 26, 1-12. [CrossRef]

50. Wunder, S. Revisiting the concept of payments for environmental services. Ecol. Econ. 2015, 117, $234-243$. [CrossRef]

51. Sanglestsawai, S.; Rejesus, R.M.; Yorobe, J.M. Economic impacts of integrated pest management (IPM) farmer field schools (FFS): Evidence from onion farmers in the Philippines. Agric. Econ. 2015, 46, 149-162. [CrossRef]

52. Zhang, Q.; Xiao, H.; Duan, M.; Zhang, X.; Yu, Z. Farmers' attitudes towards the introduction of agri-environmental measures in agricultural infrastructure projects in China: Evidence from Beijing and Changsha. Land Use Policy 2015, 49, 92-103. [CrossRef]

53. Comer, S.; Ekanem, E.; Muhammad, S.; Singh, S.P.; Tegegne, F. Sustainable and Conventional Farmers: A Comparison of Socio-Economic Characteristics, Attitude, and Beliefs. J. Sustain. Agric. 1999, 15, $29-45$. [CrossRef]

54. Reardon, T.; Barrett, C.B.; Berdegué, J.A.; Swinnen, J.F.M. Agrifood Industry Transformation and Small Farmers in Developing Countries. World Dev. 2009, 37, 1717-1727. [CrossRef]

Publisher's Note: MDPI stays neutral with regard to jurisdictional claims in published maps and institutional affiliations. 